\title{
Influence of Calcium and Magnesium on the Growth of Rhizobium
}

\author{
BY J. M. VINCENT \\ Microbiology Laboratory, School of Agriculture, University of Sydney, Australia
}

(Received 14 November 1961)

\begin{abstract}
SUMMARY
Growth of Rhizobium trifolii in a defined medium reflected the supply of $\mathrm{Ca}^{2+}$ and $\mathrm{Mg}^{2+}$ (subsequently $\mathrm{Ca}$ and $\mathrm{Mg}$, respectively) in distinctive fashion. Deficiency of $\mathrm{Ca}$, in the presence of sufficient $\mathrm{Mg}$, caused reduction in growth rate, the level of maximum growth and the proportion of viable cells. Such Ca-deprived cells were markedly swollen and vacuolated. On the other hand, although shortage of $\mathrm{Mg}$ (Ca sufficient) was without effect on growth rate down to the lowest concentration at which growth occurred, maximum growth and the proportion of viable organisms were markedly decreased. Mg-deficient organisms were appreciably elongated. Signs of Ca deficiency became apparent at less than 0.025 mM, and Mg deficiency at less than $0.1 \mathrm{~mm}$, most markedly in the range below $0.5 \mathrm{~mm}$. Additionally there was a need for total divalent cations of the order of $0.4-0.6 \mathrm{~mm}$. This could be met by either $\mathrm{Ca}$ or $\mathrm{Mg}$ provided both were sufficient for their maximum specific effect.
\end{abstract}

\section{INTRODUCTION}

Norris $(1958,1959)$ reopened the question of the need of Rhizobium for calcium. He was able to maintain a large number of strains in serial subculture in a medium free from detectable calcium; by the same method dependence on magnesium was readily shown. Magnesium seems in fact to be essential for all bacteria that have so far been studied critically, as one would expect from its known role as co-factor, but evidence for dependence on calcium is less common. Such an effect has however been shown for most species and strains examined of Azotobacter (Horner \& Burk, 1934; Norris \& Jensen, 1957), for Nitrosomonas (Kingma Boltjes, 1935), Bacillus (Brewer et al. 1946; Feeney \& Garibaldi, 1948), Lactobacillus (Yu \& Sinnhuber, 1955), Brucella (McCullough et al. 1947) and in some photosynthetic bacteria (Foster, 1944; Hutner, 1946). A marked requirement for calcium has also been ascribed to Rhizobium but, as pointed out by Norris, not all the evidence is valid. However, the stimulation obtained by Pitz (1916) when calcium was added to a defined medium appears to have been real, as do the responses reported by Allyn \& Baldwin (1932) and McCalla (1937), the latter in a clay having already adequate magnesium. More recently Ferry, Blachère \& Obaton (1959) showed that Rhizobium meliloti responded to calcium. Bergersen (1961) also showed responses by this and several other species.

Calcium response and the more striking magnesium effect with the rhizobia of the temperate legumes (Rhizobium trifolii, $R$. meliloti) have been demonstrated in this laboratory by Davies, Mullens \& Colburn (unpublished data). These observations were based on detailed growth curves obtained under conditions which per- 
mitted large populations (about $5 \times 10^{9}$ organisms $/ \mathrm{ml}$.) to be attained. Clear responses were established when using a defined medium without special purification. The main trend of our results has been recently reported, particularly the striking cytological abnormalities associated with a deficiency of either calcium or magnesium (Vincent \& Colburn, 1961).

Certain points of technique and procedure that need to be observed in investigations of this kind have often been overlooked. These include the following. (i) Readings to be sufficiently frequent to enable growth characteristics to be established. (ii) Other conditions of growth (e.g. nutrients, aeration) to be adequate so that the factor under test will be limiting. (iii) The medium to be chosen so that ions of one charge can be varied without concomitant variations in ions of the opposite charge, except when it has been shown that such variation does not affect growth. (iv) The specific effect of a particular ion to be distinguished from possible non-specific effects associated with the total ionic concentration. (v) Precipitation from the growth medium to be avoided by working within the solubility range of all constituents and, where necessary, by modifying sterilization procedures. The present paper applies these principles in a detailed study of the calcium and magnesium requirements of a strain of Rhizobium trifolii. Its chief conclusions have, however, been substantiated with several other strains of this species and with strains of $\boldsymbol{R}$. meliloti.

\section{METHODS}

Organism. A non-gummy variant of Rhizobium trifolii (SU 298/531) was chosen for detailed study because it maintained more even turbidity in the course of the whole growth curve.

Medium. A defined medium, modified slightly from that of Norris (1958), was able to support good growth without the addition of any other organic material. The constant part of the medium consisted of $0.45 \mathrm{~g}$. $\mathrm{Na}_{2} \mathrm{HPO}_{4} \cdot 12 \mathrm{H}_{2} \mathrm{O} ; 0.029 \mathrm{~g}$. $\mathrm{Na}_{2} \mathrm{SO}_{4}, 0.6 \mathrm{~g} . \mathrm{KNO}_{3} ; 0.01 \mathrm{~g} . \mathrm{FeCl}_{3} \cdot 6 \mathrm{H}_{2} \mathrm{O} ; 10 \mathrm{~g}$. mannitol; $100 \mu \mathrm{g}$. thiamine hydrochloride; $0.5 \mu \mathrm{g}$. biotin; in 11 . twice glass-distilled water. Calcium and magnesium were supplied as chlorides so that the concentration of anion would be unaffected by variation in the relative amounts of the cations. The maximum concentration of divalent cation $(1 \mathrm{~mm})$ was such that all salts remained in solution at $\mathrm{pH} 6$, provided the calcium chloride and magnesium chloride solutions were sterilized separately and added to the rest of the medium aseptically. All chemicals, except the vitamins, were of analytical grade. Traces of divalent cations already present in the complete medium were kindly determined by Dr B. Davey by the atomic absorption method. Calcium in the medium containing $0.5 \mathrm{~mm}$ magnesium was $0.006 \mathrm{~mm}(0.25$ p.p.m.); magnesium in the medium with $0.5 \mathrm{~mm}$ calcium was $0.007 \mathrm{~mm}(0.16$ p.p.m.). Glassware was cleaned with chromic + sulphuric acid, rinsed several times in tap water and then twice with glass-distilled water.

The value $\mathrm{pH} 6$ for the medium was chosen in the first instance because it allowed abundant and rapid growth of the organism whilst avoiding difficulties of solubility at higher concentrations of cations. Several experiments were, however, conducted at other $\mathrm{pH}$ levels.

Growth vessels and incubation. Medium (10 ml.) was dispensed into optically matched $\perp$ tubes, and aeration obtained by rocking (twenty-six times a minute, 
3 in. horizontal displacement) so that the shallow layer of the liquid moved from one end of the $\perp$ to the other. Incubation was at $28^{\circ}$ in a controlled water bath.

Inoculum. Surface growth at 3 days on yeast mannitol agar, but without $\mathrm{CaCO}_{3}$ was rubbed off in $10 \mathrm{ml}$. sterile glass-distilled water and adjusted turbidimetrically, to provide about $20 \times 10^{6}$ organisms per $\perp$ tube when dispensed as two drops from a standardized dropping pipette. The actual viable count of the inoculum used was determined on each occasion.

Determination of growth. Amounts of growth were determined turbidimetrically in the EEL photoelectric colorimeter (Evans Electroselenium Ltd., Harlow, Essex) with the green (404) filter. Turbidity readings greater than 30 on this intrument departed significantly from a linear relationship to concentration of organism. The readings were adjusted to conform with the extrapolated straight line of a curve constructed from a series of dilutions of a concentrated suspension. Comparisons were made with the total count on a number of occasions and in general the relationship was of the order $1 \mathrm{EEL}$ unit $=50 \times 10^{6}$ organisms $/ \mathrm{ml}$. with little difference between young $(28 \mathrm{hr}$.) and old $(100 \mathrm{hr}$.) growth. Growth was however affected by the presence or absence of calcium (e.g. with calcium, $60 \times 10^{8} / \mathrm{ml}$./unit; without, $39 \times 10^{6} / \mathrm{ml}$.). The smaller value in the absence of calcium reflects the larger average dimensions of the deprived organisms.

Growth rates $(r)$ based on logarithms to base 10, time in hr., were calculated as the line of best fit for readings in the logarithmic phase. Mean generation time can be calculated as $(\log 2) / r$, and has approximated to $3-4 \mathrm{hr}$. for the complete medium. Specific growth rate $(\mu)=\mathbf{2 \cdot 3} r$. From earlier experiments which had been continued for at least $168 \mathrm{hr}$., it was apparent that the maximum stationary growth could be determined more conveniently at 96-100 hr. Accurate determination of lag time is difficult in experiments of this nature, except by direct counting, which is time-consuming and imposes such limitations on replication as to be hardly practicable for regular use. Lag period determinations have therefore been limited to special cases.

The values quoted for each treatment are based on three to five, usually four, replicate tubes.

\section{RESULTS}

\section{General}

The results of one of the earlier experiments, in which the total concentration of divalent cations was kept constant at two values, are briefly summarized in Table 1. Comparison involving calcium deficiency can be made between treatments 1 and 2,4 and 5 (same total divalent cations) and between 1 and 5 (same magnesium concentration \pm calcium). In either case the response to calcium is clear. In this, and in some other experiments, a small amount of growth occurred when no magnesium was added. The results of a similarly planned, but more detailed, experiment are given in Table 2 . In this case the characteristics of early growth, before turbidity reached a degree suitable for measurement in the colorimeter, were determined by viable and total counts, each at three times. Examination of the detailed growth curves in this experiment has shown that the logarithmic phase was maintained between 12 and $46 \mathrm{hr}$. Valid estimates of growth rate could therefore be made by using turbidity data representing the later part of the logarithmic phase. In fact 
such rate determinations agreed very well with those based on direct counts at an earlier stage of growth.

All three estimates of the growth rate showed a clear response to calcium. The stationary population $(90 \mathrm{hr}$.) also showed a marked response to this element, but the lag time was unaffected. In this and some other experiments, the tubes without added magnesium did not show any growth.

Table 1. Response of Rhizobium trifolii, strain SU298/531 to calcium and magnesium

\begin{tabular}{|c|c|c|c|c|c|c|}
\hline \multirow{4}{*}{$\begin{array}{c}\text { Treatment } \\
\text { no. }\end{array}$} & \multicolumn{6}{|c|}{ Inoculum $=0.12 \times 10^{6}$ viable organisms $/ \mathrm{ml}$. } \\
\hline & \multirow{2}{*}{\multicolumn{2}{|c|}{ Concentration (mM) of }} & \multicolumn{4}{|c|}{ Growth } \\
\hline & & & \multicolumn{2}{|c|}{$\begin{array}{l}\text { Turbidity } \\
\text { (EEL units) }\end{array}$} & \multicolumn{2}{|c|}{$\begin{array}{c}\text { Organisms } \\
\times 10^{-6} / \mathrm{ml}\end{array}$} \\
\hline & Calcium & Magnesium & $40 \mathrm{hr}$. & 97 hr. & $40 \mathrm{hr}$. & $97 \mathrm{hr}$. \\
\hline 1 & 0.5 & $0 \cdot 5$ & $12 \cdot 9$ & 109 & 775 & 6450 \\
\hline $\mathbf{2}$ & $\mathbf{0}$ & $1 \cdot 0$ & $4 \cdot 0$ & $\mathbf{7 4}$ & 156 & 2900 \\
\hline 3 & $\mathbf{1} \cdot \mathbf{0}$ & $\mathbf{0}$ & $1 \cdot 1$ & 4 & 66 & 240 \\
\hline 4 & 0.25 & $0 \cdot 25$ & $9 \cdot 4$ & 96 & 565 & 5750 \\
\hline $\mathbf{5}$ & $\mathbf{0}$ & 0.5 & $\mathbf{2 \cdot 3}$ & $\mathbf{5 7}$ & 90 & 2200 \\
\hline 6 & 0.5 & 0 & $0 \cdot 3$ & 4 & 18 & 220 \\
\hline
\end{tabular}

Table 2. Growth constants with and without added calcium and magnesium

Inoculum $=2.5 \times 10^{6}$ viable organisms $/ \mathrm{ml}$.

\begin{tabular}{|c|c|c|c|c|c|c|}
\hline \multirow{2}{*}{\multicolumn{2}{|c|}{ Concentration (mM) of }} & \multirow[b]{2}{*}{$\begin{array}{l}\text { Lag time } \\
\text { (hr.) }\end{array}$} & \multicolumn{3}{|c|}{ Growth rate based on } & \multirow[b]{2}{*}{ Growth at $90 \mathrm{hr} . *$} \\
\hline & & & $\begin{array}{c}\text { Viable } \\
\text { counts } \\
16-23 \mathrm{hr} \text {. }\end{array}$ & $\begin{array}{c}\text { Total } \\
\text { counts } \\
\text { 18-29 hr. }\end{array}$ & $\begin{array}{l}\text { Turbidity } \\
\mathbf{4 0 - 4 6} \mathrm{hr} .\end{array}$ & \\
\hline 0.25 & 0.25 & 12 & 0.067 & 0.076 & 0.070 & $78(5600)$ \\
\hline $\mathbf{0}$ & 0.5 & 12 & 0.051 & 0.048 & 0.059 & $24(1150)$ \\
\hline 0.5 & 0 & No $g$ & wth detecte & & & \\
\hline
\end{tabular}

* Turbidity given in EEL units; bracketed values give estimates of total cells in millions, based on factors appropriate to experiment, treatment and age of culture.

Total concentration of cations. Before proceeding to more detailed studies of growth responses with graded doses of calcium and magnesium, it seemed desirable to establish the effect of the total concentration of these ions. The data given in Table 1 (treatments 1 and 4) had already indicated that any effect above $0.5 \mathrm{~mm}$ was likely to be small. Table 3 combines the results of two experiments in the range 0.1 to $0.8 \mathrm{~mm}$ divalent cations. The stationary population reflected the total concentrations of divalent cations, particularly between 0.1 and $0.2 \mathrm{~mm}$, although the growth rate was unaffected. The total effect was independent of the relative amounts of calcium and magnesium, each at least $0.05 \mathrm{~mm}$.

More detailed attention could therefore be given to lower concentrations of either ion in the region of total cation concentration, $0 \cdot 4$ to $0.6 \mathrm{~mm}$. 
Table 3. Influence of total concentration of divalent cations on growth

\begin{tabular}{|c|c|c|c|c|c|c|}
\hline \multirow{2}{*}{$\begin{array}{c}\text { Total } \\
\text { divalent } \\
\text { cations } \\
(\mathrm{mm})\end{array}$} & \multicolumn{2}{|c|}{ Concentration (mM) of } & \multicolumn{2}{|c|}{ Growth rate* } & \multicolumn{2}{|c|}{$\begin{array}{l}\text { Growth at } 100 \mathrm{hr} . \dagger \\
\text { (EEL units) }\end{array}$} \\
\hline & $\mathbf{C a}$ & $\mathrm{Mg}$ & Expt. 1 & Expt. 2 & Expt. 1 & Expt. 2 \\
\hline $0 \cdot 8$ & $\begin{array}{l}0 \cdot 7 \\
0 \cdot 1\end{array}$ & $\begin{array}{l}0 \cdot 1 \\
0 \cdot 7\end{array}$ & $\begin{array}{l}0 \cdot 092 \\
0 \cdot 088\end{array}$ & - & $\begin{array}{l}89 \\
83\end{array}$ & - \\
\hline $0 \cdot 6$ & $\begin{array}{l}0 \cdot 5 \\
0 \cdot 1\end{array}$ & $\begin{array}{l}0 \cdot 1 \\
0 \cdot 5\end{array}$ & $\begin{array}{l}0.084 \\
0.081\end{array}$ & - & $\begin{array}{l}85 \\
78\end{array}$ & - \\
\hline $0 \cdot 4$ & $\begin{array}{l}0 \cdot 35 \\
0 \cdot 3 \\
0 \cdot 2 \\
0 \cdot 1 \\
0 \cdot 05\end{array}$ & $\begin{array}{l}0 \cdot 05 \\
0 \cdot 1 \\
0 \cdot 2 \\
0 \cdot 3 \\
0 \cdot 35\end{array}$ & $\begin{array}{c}-\overline{084} \\
0.080 \\
0.087 \\
-\end{array}$ & $\begin{array}{c}0.079 \\
- \\
- \\
\overline{0.080}\end{array}$ & $\begin{array}{l}- \\
72 \\
76 \\
75 \\
-\end{array}$ & $\frac{73}{-}$ \\
\hline $0 \cdot 3$ & $\begin{array}{l}0.25 \\
0 \cdot 05\end{array}$ & $\begin{array}{l}0.05 \\
0 \cdot 25\end{array}$ & - & $\begin{array}{l}0.074 \\
0.077\end{array}$ & - & $\begin{array}{l}65 \\
65\end{array}$ \\
\hline $0 \cdot 2$ & $\begin{array}{l}0 \cdot 15 \\
0 \cdot 1 \\
0 \cdot 1 \\
0 \cdot 05\end{array}$ & $\begin{array}{l}0 \cdot 05 \\
0 \cdot 1 \\
0 \cdot 1 \\
0 \cdot 15\end{array}$ & $\begin{array}{c}- \\
0.082 \\
- \\
-\end{array}$ & $\begin{array}{c}0 \cdot 087 \\
-\overline{0} \\
0 \cdot 078 \\
0 \cdot 076\end{array}$ & $\begin{array}{l}- \\
- \\
-\end{array}$ & $\begin{array}{l}52 \\
61 \\
55\end{array}$ \\
\hline $0 \cdot 1$ & 0.05 & 0.05 & 一 & $0 \cdot 066$ & 一 & $\mathbf{2 5}$ \\
\hline
\end{tabular}

\section{Dosage response relationships with calcium and magnesium}

Figs. 1 and 2 show detailed growth curves at limiting concentrations of calcium and magnesium, respectively. Marked differences between the growth response to the two ions are immediately apparent.

Effects of calcium. As in earlier experiments, an effect on growth rate could be demonstrated with the lowest concentration of calcium (Table 4). The difference in growth rate was sufficient to explain the spacing of the calcium curves along the time axis without any increase in lag time being involved (see also Table2). Maximum growth rate occurred at $0.005 \mathrm{~mm}$. Total growth was increased up to $0.025 \mathrm{~mm}$, though most steeply and linearly to $0.005 \mathrm{~mm}$ (Fig. 3). The relationship during the linear portion of the dose-response curve can be expressed as: $y=29+9800 x$, in which $y$ is growth as EEL units, and $x$ is the mm concentration of added Ca. Quite considerable total growth occurred even without the addition of $\mathrm{Ca}$, but from the nature of the response curve this could well be accounted for by the Ca already known to be present. (See alternate scale on the abscissa of Fig. 3 allowing for $0.006 \mathrm{~mm} \mathrm{Ca}$ already in the medium.)

Effects of magnesium. With magnesium on the other hand (Fig. 2; Table 5) growth rate and lag time at the lowest concentration $(0.001 \mathrm{mM})$ could not be distinguished from the highest. When, as in Expt. 2, growth occurred without the addition of magnesium, the rate and lag were also normal. Experiments 2 and 3 were put up at the one time to determine whether a tenfold dilution of inoculum would result in the growth rate being decreased at lower values of added magnesium. Experiment $2\left(0 \cdot 2 \times 10^{6}\right.$ organisms $/ \mathrm{ml}$.) showed an extended lag compared with Expt. $3\left(2 \cdot 4 \times 10^{6}\right.$ organisms $/ \mathrm{ml}$.), but the number of organisms in the inoculum 
had no effect on the magnesium response. Unfortunately the earlier readings that were needed for the determination of rate in Expt. 3 were not available. However, it was apparent from the similarity of the first readings for all concentrations that the early growth was independent of added magnesium in this experiment also.

Stationary growth data from four experiments plotted against concentration of added magnesium (Fig. 3$)$ showed that a linear relationship $(y=4 \cdot 9+1210 x)$ was maintained up to $0.05 \mathrm{~mm}$. Again any growth that occurred without added magnesium can be accounted for by the small amount of $\mathrm{Mg}(0.007 \mathrm{~mm})$ likely to be present in the basal medium.

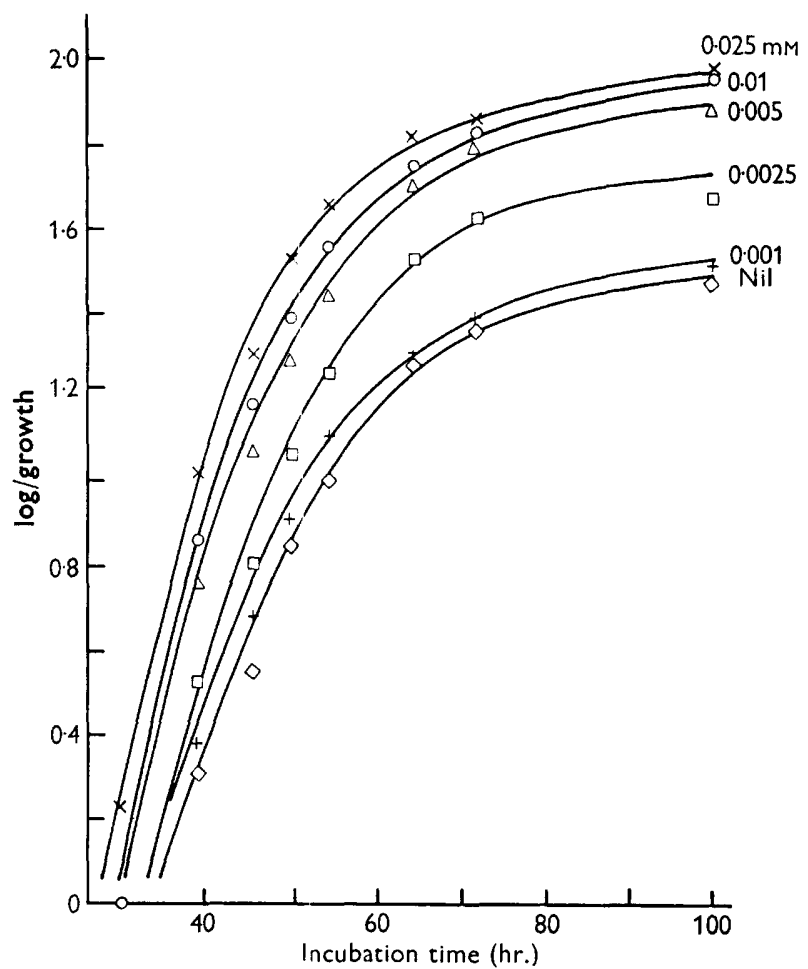

Fig. 1. Growth curves of Rhizobium trifolii with varying concentrations of calcium $(0.025 \mathrm{mM}, \times ; 0.01,0 ; 0.005, \triangle ; 0.0025, \square ; 0.001,+$, nil, $\diamond)$. Inoculum: $0.54 \times 10^{6}$ organisms $/ \mathrm{ml}$; $\log$. equivalent turbidity $=$ approx. $\mathbf{- 2 \cdot 0}$. Growth is expressed as turbidity ( 1 unit $=$ about $50 \times 10^{6}$ organisms $/ \mathrm{ml}$.). Curves for concentrations $>0.025 \mathrm{~mm}$ are practically identical with that concentration and have been omitted to avoid confusion.

Relationship of $p H$ value to need for calcium and magnesium

Table 6 combines data from two experiments and shows that calcium effects were readily demonstrated from $\mathrm{pH} \mathrm{5.5}$ to 7 . There was marked delay in the initiation of growth in one or more of the minus calcium replicates at the lowest $\mathrm{pH}$ values $(5 \cdot 5$ and $5 \cdot 8)$. Otherwise the growth rate response appeared to be independent of $\mathrm{pH}$ value. Nor could any consistent interaction be demonstrated between calcium and $\mathrm{pH}$ value in respect of total growth. Similarly the $\mathrm{pH}$ value in the range $5 \cdot 5$ to $6 \cdot 6$ was without effect on the magnesium response (Table 7 ). 


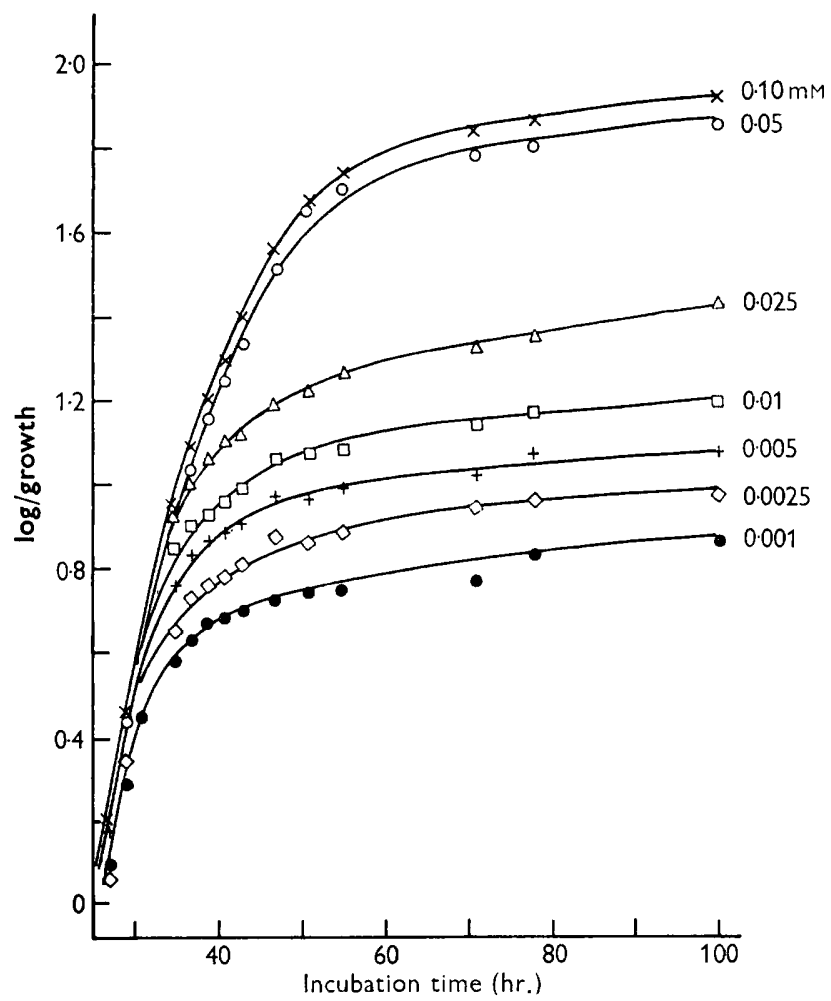

Fig. 2. Growth curves of Rhizobium trifolii with varying concentrations of magnesium $(0.10 \mathrm{~mm}, \times ; 0.05, \bigcirc ; 0.025, \triangle ; 0.01, \square ; 0.005,+; 0.0025, \diamond ; 0.001, \diamond)$. Inoculum: $1.3 \times 10^{6}$ organisms $/ \mathrm{ml}$.; log. equivalent turbidity $=$ approx. -1.4 . Growth units as for Fig. 1.

Table 4. Influence of concentration of calcium

Inoculum: $0.5 \times 10^{6}$ organisms $/ \mathrm{ml}$.

Added Ca
$(\mathrm{mM})^{*}$

$0 \cdot 10$

$0 \cdot 05$

$0 \cdot 025$

0.01

0.005

$0 \cdot 0025$

0.001

$\mathbf{0}$

Growth rate
0.084
0.085
0.080
0.086
0.082
0.070
0.052
0.053

Growth at $100 \mathrm{hr}$.

(EEL units)

100
100
99
90
78
56
34
32

* Added to medium containing $0.5 \mathrm{~mm} \mathrm{Mg}$.

$\dagger$ Differences for significance: $5 \%, 0.017 ; 1 \%, 0.023$.

Influence of calcium and magnesium on viability

A deficiency of either calcium or magnesium decreased the proportion of viable organisms. This was found for all stages of growth in the absence of calcium, and at $100 \mathrm{hr}$. for several concentrations of magnesium (Table 8). The effect of $\mathbf{M g}$ was most striking, the proportion of viable organisms being almost directly related to concentration of magnesium. 
Table 6. Calcium response in relation to $\mathrm{pH}$ value

Total divalent cations $=0.5 \mathrm{~mm}$

\begin{tabular}{|c|c|c|c|c|c|}
\hline \multirow[b]{2}{*}{ pH } & \multirow[b]{2}{*}{ Expt. } & \multicolumn{2}{|c|}{$\begin{array}{l}\text { Growth rate.* } \\
\text { Calcium (mM) }\end{array}$} & \multicolumn{2}{|c|}{$\begin{array}{l}\text { Growth at } 100 \mathrm{hr} \text {. } \\
\text { (EEL units). } \\
\text { Calcium (mM) }\end{array}$} \\
\hline & & $0 \cdot 25$ & $\mathbf{0}$ & 0.25 & 0 \\
\hline $5 \cdot 5$ & 2 & 0.076 & $0.060 \dagger$ & 94 & $29 \dagger$ \\
\hline $5 \cdot 8$ & 1 & $0 \cdot 086$ & n.d. $\neq$ & 71 & $52 \ddagger$ \\
\hline $5 \cdot 9$ & 2 & 0.078 & 0.052 & 96 & 31 \\
\hline $6 \cdot 1$ & 1 & $0 \cdot 091$ & 0.071 & 73 & 41 \\
\hline $6 \cdot 3$ & 2 & 0.075 & 0.053 & 91 & 37 \\
\hline 6.5 & 1 & 0.083 & 0.070 & 72 & 65 \\
\hline $6 \cdot 6$ & 2 & 0.075 & $0 \cdot 038$ & 88 & 27 \\
\hline $7 \cdot 0$ & 1 & 0.081 & 0.076 & 70 & 60 \\
\hline
\end{tabular}

Notes

* Differences for significance in Expt. 2: $5 \%$, 0.010; $1 \%$ 0.013. Differences in Expt. 1 did not reach significance, but are in good agreement with the later experiment.

$\dagger$ Based on three of the four replicates. The fourth failed to grow in $100 \mathrm{hr}$.

$\ddagger$ Growth too late for reliable determination of rate; maximum growth based on the two of the three tubes that grew.

Table 7. Magnesium response in relation to $\mathrm{pH}$ value

All treatments contained $0.5 \mathrm{~mm}$ Ca.

$\begin{array}{lllll}\text { pH } & \overbrace{0.1}^{\text {Growth rate }} & 0.01 & 0.1 & 0.01 \\ 5.5 & 0.077 & 0.078 & 93 & 10.2 \\ 5.9 & 0.080 & 0.076 & 89 & 11 \cdot 3 \\ 6.2 & 0.074 & 0.084 & 94 & 12.8 \\ 6.6 & 0.080 & 0.073 & 92 & 10.7\end{array}$

Table 8. Ratio of viable to total organisms, in relation to calcium and magnesium

\begin{tabular}{|c|c|c|c|c|}
\hline \multicolumn{5}{|c|}{ Time (hr.) } \\
\hline 28 & 52 & 76 & 96 & 100 \\
\hline \multicolumn{5}{|c|}{ Ratio of viable/total count } \\
\hline 0.9 & $1 \cdot 2,1 \cdot 1$ & $1 \cdot 0$ & $0 \cdot 8$ & $1 \cdot 0,0.9$ \\
\hline 0.5 & $0 \cdot 4,0.2$ & $0 \cdot 3$ & $0 \cdot 6$ & $0.3,0.4$ \\
\hline
\end{tabular}

All at $100 \mathrm{hr}$.

(b) Magnesium $\dagger(\mathrm{mm}) \quad 0 \cdot 1$

$\begin{array}{ll}0.1 & 0 \cdot 7,0.8 \\ 0.01 & 0 \cdot 1 \\ 0.001 & 0.02 \\ 0 & 0.003\end{array}$

* All tubes contained $0.4 \mathrm{~mm} \mathrm{Mg}$.

+ All tubes contained $0.5 \mathrm{~mm} \mathrm{Ca}$. 


\section{DISCUSSION}

There is no doubt that a deficiency of either magnesium or calcium decreased the total amount of growth of the strains of Rhizobium trifolii and of the several cultures of $R$. meliloti studied. The signs of deficiency in the two cases are however distinctive. Although a relatively large amount of magnesium (0.05-0.1 mM) was required for maximum total growth, the growth rate was unaffected at concentrations at least as low as $\mathbf{0 . 0 0 7} \mathrm{mm}$. On the basis of total growth, shortage of calcium only became apparent below $0.01 \mathrm{~mm}$, but then the dose response relationship was a very steep one. Below $0.005 \mathrm{~mm}$ added $\mathrm{Ca}$, the growth rate was also affected.

These results show the need for continuous growth data, rather than depending on roughly quantitative assessments of growth in serial subculture. The values thus obtained have also to be related to the concentration of the substance concerned. It is not surprising, for example, that Loneragan \& Dowling (1958) failed to obtain any response to added calcium in a medium already containing $0.16 \mathrm{~mm} \mathrm{Ca}$. Examination of Fig. 3 explains why it is so much easier to demonstrate a deficiency of magnesium than calcium. An equal increment of total growth requires about an eight times greater molar concentration of $\mathrm{Mg}$ than of $\mathrm{Ca}$; a large part of the organism's requirement for $\mathrm{Ca}$ can obviously be met by a low concentration of $\mathrm{Ca}$ as impurity. The small amount of growth that occurred in some experiments without added magnesium could also be attributed to a low concentration of $\mathrm{Mg}$ as impurity.

It is also important to pay attention to other signs of nutrient deficiency, e.g. in the present instance decreased viability and abnormal cell morphology. The latter reflects very clearly the element concerned. The grossly swollen and vacuolated cells obtained with a $\mathrm{Ca}$ deficiency are the more striking and suggest a loss of rigidity in the cell wall. It might have been expected that this condition would have been reflected in greater osmotic fragility but, although some experiments in which calcium-deficient organisms were exposed to distilled water gave indications of swelling and accelerated rate of loss of viability, the experiments as a whole were inconclusive about this point. Analyses recently carried out in this laboratory by Mrs B. A. Humphrey (personal communication) show that calcium-deprived organisms contained only about one-tenth the amount of calcium as found in normal organisms. Almost all of the calcium of the deficient cells is located in the wall fraction. It seems likely that Ca plays a role in providing a rigid cell wall. This is being investigated.

Closer examination of organisms grown in a medium markedly deficient in magnesium have shown them to be appreciably longer than normal. This elongation is not unlike the condition observed with other bacteria grown in a magnesiumdeficient medium and commonly attributed to a failure of normal cell division. This might also explain the very low viability that was found in the present experiments at the lower limiting concentrations of magnesium.

I would like to thank Mrs C. H. Jancey for expert assistance throughout the course of this work. Preliminary experiments were undertaken in this laboratory by Miss Jean Davies, Miss Rosemary Mullens and the late Mr J. Colburn as honours 
and post-graduate projects. The work has been supported by the Rural Credits

Division of the Commonwealth Reserve Bank, the Research Committee of the University of Sydney and Wheat Industry Research Funds.

\section{REFERENCES}

Allyn, W. P. \& Baldwin, I. L. (1932). Oxidation-reduction potentials in relation to the growth of an aerobic form of bacterium. J. Bact. 23, 369.

Bergersen, F. J. (1961). The growth of Rhizobium in synthetic media. Aust. J. biol. Sci. $14,349$.

Brewer, C. R., McCullough, W. G., Miles, R. C., Roessler, W. G., Herbst, E. J. \& Howe, A. F. (1946). Studies on the nutritional requirements of Bacillus anthracis. Arch. Biochem. 10, 65.

Feeney, R. E. \& Garibaldi, J. A. (1948). Studies on the mineral nutrition of the subtilinproducing strain of Bacillus subtilis. Arch. Biochem. 17, 447.

Ferry, P., Blachère, H. \& Obaton, M. (1959). Un milieu de culture synthétique pour Rhizobium meliloti. Ann. Agron. Paris, p. 219.

Foster, J. W. (1944). Oxidation of alcohols by non-sulphur photosynthetic bacteria. J. Bact. 47, 355.

Horner, C. K. \& BURK, D. (1934). Magnesium, calcium and iron requirements for growth of Azotobacter in free and fixed nitrogen. J. agric. Res. 48, 981.

Hutner, S. H. (1946). Organic growth essentials for the aerobic nonsulfur photosynthetic bacteria. J. Bact. 52, 213.

Kingma BoltJes, T. Y. (1935). Untersuchungen über die nitrifizirenden Bakterien. Arch. Mikrobiol. 6, 79. (Quoted Meiklejohn (1954). Symp. Soc. gen. Microbiol. 4, 68.)

Loneragan, J. F. \& Dowling, E. J. (1958). The interaction of calcium and hydrogen ions in the nodulation of subterranean clover. Aust. J. agric. Res. 9, 464.

McCalla, T. M. (1937). The behaviour of legume bacteria (Rhizobium) in relation to exchangeable calcium and hydrogen ion concentration of the colloidal fraction of the soil. Res. Bull. Mo. agric. exp. Sta. 256.

McCullough, W. G., Mills, R. C., Herbst, E. J., Roessler, W. G. \& Brewer, C. R. (1947). Studies on the nutritional requirements of Brucella suis. J. Bact. 53, 5.

Norris, D. (1958). Rhizobium needs magnesium, not calcium. Nature, Lond. 182, 734.

Norris, D. (1959). The role of calcium and magnesium in the nutrition of Rhizobium. Aust. J. agric. Res. 10, 561.

Norris, J. R. \& Jensen, H. L. (1957). Calcium requirements of Azotobacter. Nature, Lond. 180, 1493.

Pitz, W. (1916). Effect of elemental sulphur and of calcium sulphate on certain of the higher and lower forms of plant life. J. agric. Res. 5, 771.

Vincent, J. M. \& Colburn, J. M. (1961). Cytological abnormalities in Rhizobium trifolii due to deficiency of calcium or magnesium. Aust. J. Sci. 23, 269.

Yu, T. C. \& Sinniuber, R. O. (1955). Stimulatory effect of calcium on the growth of Lactobacillus fermenti. Proc. Soc. exp. Biol., N.Y. 88, 238. (Biol. Abstr. (1955), 29, 21804). 
